\title{
Appraisal of challenges encountered by undergraduate technology education students in other degree- awarding institution in North-Eastern Nigeria
}

\author{
F. N. Nnajiofor • M. A. Auta*
}

Department of Technology and Vocational Education, Nnamdi Azikiwe University, Awka, Nigeria.

*Corresponding author. E-mail: ma.auta@unizik.edu.ng

Accepted $16^{\text {th }}$ October, 2019.

\begin{abstract}
The purpose of the study is to appraise the problems often encountered by undergraduate technology education students in other degree awarding institutions in north-eastern Nigeria. Three purposes, research question and hypotheses guided the study. The study adopted descriptive survey research design. The area of the study was North-eastern Nigeria and the population of the study comprises of 154 bachelor degree students in the two degreeawarding institutions offering technology education programme - Federal Colleges of Education (Technical) in Gombe and Potiskum. The entire population was used for the study. The instrument used for data collection was a structured questionnaire. The instrument has a reliability coefficient of 0.77 . One hundred and forty three copies of the instrument were administered, but only 139 were properly filled and returned. Mean was used to analyze the data to answer the research questions, while z-Test was used to analyze the data for testing the three null hypotheses at 0.05 level of significance. Findings from the study indicate that undergraduate technology education students in other degree awarding institutions are encountering admission, instruction, and examination-related challenges. It is therefore recommended among others that Other degree awarding institutions should organize orientation exercise for their newly admitted students; NUC should ensure that only institutions with adequate facilities are granted the approval to mount degree programmes in technology education; Universities should ensure that the degree results of their affiliate institutions are considered, approved, and released as quickly as possible; Universities should ensure that the graduates of their affiliate institutions are timely mobilized for the NYSC.
\end{abstract}

Keywords: Challenges, technology education, degree-awarding, institutions, Nigeria.

\section{INTRODUCTION}

Education plays a key role in the socio-economic development of any nation. However, the realization of the goals of education is hinged largely on the quality of teacher preparation programme, since a nation cannot develop above the quality of its teachers. According to the European Union (2012), in an educational establishment, professional teachers are the most important determinants of the manner and ways in which a learner will perform, and it is what they know and do that should concern all. In the past, teacher training programmes at its lowest level commences at the various teachers training colleges spread across the country, at the end of the programme the graduates are awarded the teacher Grade II teacher certificate with grades recorded based on their level of performance at the end of the terminal examination. However, with the subsequent revisions of the National policy on education, the minimum qualification for teachers at all levels of the Nigerian education system was elevated to the Nigeria Certificate in Education (NCE) (Federal Republic of Nigeria 
(FRN), 2013). Consequently, most of these teachers training institutions were either upgraded to Colleges of Education (COEs) so that they can award the NCE or converted to senior secondary schools.

Teacher education programmes beyond the NCE are done in the university. At the university level, the programmes are handled by the various faculties of education through the respective departments where the programme is domiciled. The candidates for the programmes are either admitted directly from the secondary schools through the Unified Tertiary Matriculation Examination (UTME) or through the Direct Entry (DE) for those who might have earned the NCE from the various COEs across the country (Joint Admission and Matriculation Board (JAMB), 2018). This arrangement, as obtained in other academic programmes brought about crisis of access to university education as the number of universities cannot conveniently accommodate the growing number of applicants who desire to upgrade their qualification to bachelor degree or fresh entrants into the various academic programmes obtained in the university. As a panacea to the problem, the federal government, through the National Universities Commission (NUC) approved for some higher education institutions to go into affiliation with Universities of their choices so that they can run the bachelor degree programme in the various disciplines, including that of teacher education. These high institutions are referred to as other degree-awarding institutions (JAMB, 2018).

Other degree-awarding institutions in Nigeria are synonymous with university colleges obtained in other countries of the world. They are, as briefly described in the preceding paragraph, higher education institutions empowered by the NUC to run bachelor degree programmes in various disciplines in affiliation with other established universities of their choices. The degrees awarded are that of the host university, and the responsibility for regulating the programme is vested with the NUC through the host university. JAMB (2018) identified other degree-awarding institutions to include: Theological seminaries, Polytechnics, Monotechnics, and Colleges of education. Technology Education is one of the disciplines offered at the bachelor degree level in the COEs.

Technology Education is an aspect of educational processes involving the study of technologies and related sciences and the acquisition of practical skills, attitudes, understanding, and knowledge relating to occupations in various sectors of the economic and social life (FRN, 2013). It is therefore an education programme designed to equipped an individual with the knowledge, skills and aptitude needed to function in an industrial establishments either as self-employed or an employee (Auta, 2017). This aspect of education therefore, is a catalyst for the overall development of any nation and should be accorded all the attention it deserves. Students who earned a degree in technology education are expected to not only engage in paid employment, but to be employers of labour by putting into practice all the knowledge and skills they acquired in the course of their educational pursuit. However, these goals can only be achieved where favourable environment is made available for its recipients. The question now is: how are technology education students coping in the other degree-awarding institutions?

It is instructive to note that, the affiliation arrangement between the universities and the COEs have opened more access to teacher education programmes to the teeming applicants, there appears to be some challenges being faced by students undergoing programmes in these other-degree awarding institutions. These challenges can be relative to admission (Bolu-Steve et al., 2017); Instruction (Albashtawi, 2014); and Examination (Yasmin et al., 2018).

Admission related challenges are those often encountered by students prior to application and during the initial stage of their enrolment into the programme. Instruction challenge on the other hand, has to do with the challenges often encountered during the teaching and learning process in the course of their studentship. Examination related challenges include those related to the certification process; this can take the shape of semester examination, project defence as well as timely release of results. However, the nature, manner and form of its form particularly as it affects technology education students in the two institutions running the programme in north-eastern part of Nigeria are still not clear. Are the identified problems prevalent in all the institutions or individual institutions having their distinct problems? The location of the institution will therefore be utilized as the moderator variable in testing the hypotheses. This therefore become an impediment to the successes of the various strategies being put in place by the universities hosting affiliated colleges in the geo-political zone to ensure that the programmes are run with ease. This situation necessitate this study to appraise the challenges encountered by undergraduate technology education students in other degree-awarding institution in northeastern Nigeria.

\section{Purpose of the study}

The purpose of the study was to appraise the challenges encountered by undergraduate technology education students in other degree-awarding institutions in northeastern Nigeria. Specifically, the study sought to appraise the challenges encountered by undergraduate technology education students in other degree-awarding institutions in north-eastern Nigeria related to:
1. Admission;
2. Instruction; and
3. Examination of students 


\section{Research questions}

The study answered the following questions:

1. What are the admission-related challenges encountered by undergraduate technology education students in other degree-awarding institutions in northeastern Nigeria?

2. What are the instructional-related challenges encountered by undergraduate technology education students in other degree-awarding institutions in northeastern Nigeria?

3. What are the examination-related challenges encountered by undergraduate technology education students in other degree-awarding institutions in north-eastern Nigeria?

\section{Hypotheses}

The following null hypotheses were tested at 0.05 level of significance:

1. There is no significant difference between the mean opinion of technology education students of F.C.E. (T) Potiskum and F.C.E. (T) Gombe on admission-related challenges encountered by undergraduate technology education students in other degree-awarding institutions in north-eastern Nigeria.

2. There is no significant difference between the mean opinion of technology education students of F.C.E. (T) Potiskum and F.C.E. (T) Gombe on instructional-related challenges encountered by undergraduate technology education students in other degree-awarding institutions in north-eastern Nigeria.

3. There is no significant difference between the mean opinion of technology education students of F.C.E. (T) Potiskum and F.C.E. (T) Gombe on examination-related challenges encountered by undergraduate technology education students in other degree-awarding institutions in north-eastern Nigeria.

\section{MATERIALS AND METHODS}

The study adopted descriptive survey research design. The area of the study was North-eastern Nigeria and the population of the study comprises of 154 bachelor degree students in the two degree-awarding institutions offering technology education programme- Federal Colleges of Education (Technical) in Gombe, Gombe State and Potiskum, Yobe State. There was no sampling; therefore, the entire population was used for the study. The instrument used for data collection was 36 items structured questionnaire developed by the researchers after thorough review of related literature as well as the personal observation of the activities of the other degree awarding institutions. The instrument has four sections A$D$, section A sought for the salient demographic characteristics of the respondents, while sections $B, C$, and $\mathrm{D}$ sought for data relating to research questions 1,2 and 3 respectively and for testing the hypotheses. The instrument was validated by three experts who are lecturers in the Department of Technology and Vocational Education, Nnamdi Azikiwe University, Awka. The instrument was trial-tested on 10 undergraduate technology education students at the Federal College of Education (Technical), Umunze, Anambra State. Cronbach Alpha was used to analyze the data in order to establish the reliability of the instrument, and a reliability coefficient of 0.77 was obtained. One hundred and forty three copies of the instrument were administered on the respondents with the help of their lecturers during lecture sessions, but only 139 were properly filled and returned.

Mean was used to analyze the data to answer the research questions. Any item with a mean score of 3.50 which is the lower limit of "Agree" and above was considered as a challenge encountered by undergraduate technology education students in other degree-awarding institutions in north-eastern Nigeria. z-Test was used to analyze the data for testing the three null hypotheses at 0.05 level of significance. Where the $p$-value is greater than the level of significance (0.05), the null hypothesis will be accepted, where on the other hand, the less than or equal $\leq$ to the level of significance, the null hypotheses will be rejected.

\section{RESULTS}

\section{Research question 1}

The data presented in Table 1 revealed that the mean rating of the respondents ranges from 3.52 to 4.07 . This indicates that the respondents agreed with all the admission-related challenges presented to them as what they encountered in their respective degree-awarding institutions.

\section{Research question 2}

Data presented in Table 2 revealed that the mean response of the respondents ranges from 2.34 to 4.21 . Four items $(12,13,15,17$ and 19) had their mean value fallen below 3.50, indicating that the respondents disagreed with those instructional-related challenges presented to them. The other nine items had their mean value above 3.50 which is an indication that they are the instructional-related problems technology education students encountered in the other degree awarding institutions.

\section{Research question 3}

Data on Table 3 indicated that the mean response of the respondents ranges from 2.21 to 4.81 . Items $24,27,28$, 29 and 30 had their mean value fallen below 3.50; while, 
Table 1. Mean and standard deviation on admission-related challenges encountered by undergraduate technology education students in other degree-awarding institutions.

\begin{tabular}{clcc}
\hline $\mathbf{S} / \mathbf{N}$ & \multicolumn{1}{c}{ Statement } & Mean & Remark \\
\hline 1 & Delay in the release of admission list of prospective students & 3.52 & Agree \\
2 & Difficulty in JAMB regularization of admission status & 3.67 & Agree \\
3 & Offer of admission to programmes that the candidates did not apply for & 4.04 & Agree \\
4 & Charging acceptance and registration fees above that of the parent university & 3.85 & Agree \\
5 & Delay in issuance of matriculation/registration number & 3.92 & Agree \\
6 & Delay in the conduct of matriculation ceremony & 3.66 & Agree \\
7 & Non conduct of orientation exercises for the newly admitted students & 4.07 & Agree \\
\hline
\end{tabular}

$\mathrm{N}=139$

Table 2. Mean and standard deviation on instructional-related challenges encountered by undergraduate technology education students in other degree-awarding institutions.

\begin{tabular}{|c|c|c|c|}
\hline $\mathbf{S} / \mathbf{N}$ & Statement & Mean & Remark \\
\hline 8 & Lecturers do not attend classes as scheduled on the lecture time-table & 3.76 & Agree \\
\hline 9 & Inadequate or near-absence of workshop exercises & 3.91 & Agree \\
\hline 10 & Inadequate classrooms to accommodate students during lectures & 3.82 & Agree \\
\hline 11 & Lecturers are over-stretched with many courses to handle & 4.21 & Agree \\
\hline 12 & Library facilities are not adequately available & 3.19 & Disagree \\
\hline 13 & Undergraduate students are denied access to certain library resources & 2.64 & Disagree \\
\hline 14 & Often there are no consumables in the workshop & 3.71 & Agree \\
\hline 15 & Students come with their personal drawing boards during drawing classes & 3.15 & Disagree \\
\hline 16 & No provision for internet facilities on campus for ease of access to online resources & 4.02 & Agree \\
\hline 17 & Lecture time-table are not released immediately at the beginning of the semester & 2.34 & Disagree \\
\hline 18 & HODs don't supervise to ensure that lecturers attend to their classes & 3.78 & Agree \\
\hline 19 & Lab attendants are not always available for practical exercise & 3.51 & Agree \\
\hline 20 & $\begin{array}{l}\text { Lecturers often "relax" at the beginning of the semester and only "rush" to make-up lost ground } \\
\text { once they realize that the semester is coming to an end }\end{array}$ & 3.83 & Agree \\
\hline
\end{tabular}

$\mathrm{N}=139$

the remaining 11 items had their mean value above 3.50 which is an indication that the eleven items are the examination-related problems technology education students encountered in the other degree awarding institutions.

\section{Hypotheses 1}

Table 4 revealed the mean response of Potiskum students (4.13) and Gombe students (4.01); the data revealed that both the Potiskum and Gombe students agreed on the admission-related challenges being encountered by technology education students in other degree awarding institutions. The data from the table also shows that there is no significant difference between mean response of Potiskum and Gombe students $(t=$ $0.68, \mathrm{df}=137, \mathrm{p}=0.24>0.05)$ on the admission-related challenges being encountered by technology education students in other degree awarding institutions.

\section{Hypotheses 2}

Data on Table 5 indicated the mean response of Potiskum students (3.84) and Gombe students (4.22); the data also shows that both the Potiskum and Gombe students agreed on the instructional-related challenges being encountered by technology education students in other degree awarding institutions. The data also shows that there is no significant difference between mean response of Potiskum and Gombe students $(t=1.25$, df $=$ 137, $p=0.18>0.05$ ) on the instructional-related challenges being encountered by technology education students in other degree awarding institutions.

\section{Hypotheses 3}

The data on Table 6 show the mean response of Potiskum students (3.91) and Gombe students (3.74); this indicated that that both the Potiskum and Gombe 
Table 3. Mean and standard deviation on examination-related challenges encountered by undergraduate technology education students in other degree-awarding institutions.

\begin{tabular}{|c|c|c|c|}
\hline $\mathbf{S} / \mathbf{N}$ & Statement & Mean & Remark \\
\hline 21 & Semester examinations don't always commence and scheduled in the calendar of events & 4.47 & Agree \\
\hline 22 & Delay in the release of semester examinations results & 4.52 & Agree \\
\hline 23 & Examination dates are rescheduled without due notice to the students & 3.62 & Agree \\
\hline 24 & $\begin{array}{l}\text { Examination questions are not set based on the subject areas covered during the teaching } \\
\text { sessions }\end{array}$ & 3.24 & Disagree \\
\hline 25 & Errors in the computation of the GPA and CGPA & 3.64 & Agree \\
\hline 26 & SIWES programmes are not supervised by the institution based supervisors & 4.08 & Agree \\
\hline 27 & Teaching practice are not supervised by the institution based supervisors & 3.01 & Disagree \\
\hline 28 & Examination materials are not adequately made available to the students during examinations & 2.21 & Disagree \\
\hline 29 & Examination halls are over-crowded during examinations & 2.33 & Disagree \\
\hline 30 & Reported cases of examination misconducts are handled with laxity & 3.22 & Disagree \\
\hline 31 & Some students sees the examination questions before the commencement of the examination & 3.61 & Agree \\
\hline 32 & Students are made to pay in cash or in kind to earn good grades after examination & 3.74 & Agree \\
\hline 33 & Lecturers forced students to buy handouts and other self-published book to earn good grades & 3.83 & Agree \\
\hline 34 & Continues assessment are not practiced, students are assessed only at the end of the semester & 3.69 & Agree \\
\hline 35 & Final degree results are delayed beyond reasonable time & 4.79 & Agree \\
\hline 36 & Students who graduated are not swiftly mobilized for NYSC & 4.81 & Agree \\
\hline
\end{tabular}

$\mathrm{N}=139$

Table 4. Summary of z-test analysis between the mean opinion of technology education students of F.C.E. (T) Potiskum and F.C.E. (T) Gombe on admission-related challenges.

\begin{tabular}{lccccccc}
\hline Position & N & Mean & SD & Df & t-value & p-value & Remarks \\
\hline Potiskum & 76 & 4.13 & 0.77 & 137 & 0.68 & 0.24 & Accept Ho \\
Gombe & 63 & 4.01 & 0.35 & & & & \\
\hline
\end{tabular}

Table 5. Summary of z-test analysis between the mean opinion of technology education students of F.C.E. (T) Potiskum and F.C.E. (T) Gombe on Instructional-related challenges.

\begin{tabular}{lccccccc}
\hline Position & N & Mean & SD & Df & t-value & p-value & Remarks \\
\hline Potiskum & 76 & 3.84 & 0.94 & 137 & 1.25 & 0.18 & Accept $H_{\circ}$ \\
Gombe & 63 & 4.22 & 0.52 & & & & \\
\hline
\end{tabular}

Table 6. Summary of z-test Analysis between the mean opinion of technology education students of F.C.E. (T) Potiskum and F.C.E. (T) Gombe on examination-related challenges.

\begin{tabular}{lccccccc}
\hline Position & N & Mean & SD & Df & t-value & p-value & Remarks \\
\hline Potiskum & 76 & 3.91 & 0.29 & 137 & 0.89 & 0.92 & Accept $\mathrm{H}_{\circ}$ \\
Gombe & 63 & 3.74 & 1.42 & & & & \\
\hline
\end{tabular}

students agreed on the examination-related challenges being encountered by technology education students in other degree awarding institutions. The data from the table also shows that there is no significant difference between mean response of Potiskum and Gombe students $(\mathrm{t}=0.89$, df $=137, \mathrm{p}=0.92>0.05)$ on the examination-related challenges being encountered by technology education students in other degree awarding institutions.

\section{DISCUSSION}

The findings of this study revealed that offer of admission to programmes that candidates did not apply for, charging of fees above the parent university, non-conduct 
of orientation exercise are some of the admission-related challenges encountered by technology education in other degree awarding institutions in north-eastern Nigeria. These findings reinforced the view of Ashraf et al. (2016) who observed that due to the limited space available in most tertiary institutions, prospective applicants are often reassigned to programmes related to their programmes of choice. It is also in agreement with the opinion of Akeem (2017) who said that high school fees is one of the impediments to the realization of the goals of tertiary education as most of the students are willing to acquire tertiary education but lack the resources needed to successfully enroll into such programmes.

The study also indicated that lecturers are overstretched with many courses to handle, near absence of workshop for practical, non-provision of internet facilities on campus, non-supervision of instruction by HODs, inadequate classrooms to accommodate students are some of the instructional-related challenges encountered by technology education in other degree awarding institutions in north-eastern Nigeria. These findings concurred with that of Limon (2016) who discovered that inadequate funding has been a barrier to achieving effective instruction in most tertiary institutions. According to the author, provision of adequate instructional facilities both in quality and quantity is a key to achieving the lofty goals of instructional programmes particularly those that have relationship with skill acquisitions.

Non-commencement of semester examination as scheduled, non-release of semester results, lack of supervision of SIWES exercise, allowing students to see examination questions before time, forcing students to buy handouts, errors in the computation of GPA and CGPA, non-release of degree results on time, and delay in mobilization of graduates for the NYSC programmes are some of the examination-related challenges encountered by technology education in other degree awarding institutions in north-eastern Nigeria. This finding is in contrast with the views of Kuranchie et al. (2014) who opined that most tertiary institutions have zero tolerance to all illicit behaviours such as selling of grades and other unwholesome behaviours; however, the findings aligned with the views of Ajayi and Adeniji (2009) who argued that tertiary institutions in Nigeria are becoming a shadow of what they used to be, because in the current dispensation, students are at liberty to earn grades of their choices when they are ready to engage in some sort of unwholesome behaviours such as buying their way either in "cash" or in "kind". It also reinforced the findings of Ogbonnaya (n.d) who discovered that lack of adequate supervision of SIWES programme enable most of students to developed truant behaviour when posted for the exercise. This scenario continues to threaten the realization of the goals of the programme.

The findings from the study also indicated that the students from the two study institutions were unanimous in their agreement of the existence of these challenges; therefore, it can be inferred that the existence of these challenges is real across several institutions. That was aptly observed by Ajayi and Harstrup (n.d) who are of the view that the challenges confronting tertiary institutions in Nigeria is not peculiar to one institution or region, in fact, according to the authors, it is a national issues which requires a concerted effort to mitigate.

\section{CONCLUSION}

Based on the findings of this study, it can be concluded that existence of admission, instruction, and examination related challenges is real in the other degree awarding institutions offering technology education programme in North-Eastern Nigeria. When these challenges are not properly addressed, it will threaten the realization of the goal of the affiliation programmes being championed by the National Universities Commission (NUC).

\section{RECOMMENDATIONS}

1. Other degree awarding institutions should organize orientation exercise for their newly admitted students.

2. Universities should ensure that their affiliate institutions do not charge school fees above the fee charge by the mother university.

3. NUC should ensure that only institutions with adequate facilities are granted the approval to mount degree programmes in technology education.

4. Management of other degree awarding institutions should ensure that HODs perform their traditional role of instructional supervision.

5. Universities should ensure that their affiliate institutions commence examination as schedule, and results are timely moderated and release to the students.

6 . Universities should ensure that the degree results of their affiliate institutions are considered, approved, and release as quickly as possible.

7. Universities should ensure that the graduates of their affiliate institutions are timely mobilize for the NYSC.

\section{REFERENCES}

Ashraf MA, Osman R, Ratan RSA (2016). Determinants of quality of education in private universities for students' perspectives: A case study of Bangladesh. Q. A. in Educ. 24(1):123-138. Online access http://doi.org/10.1108/QAE-09-2013-0040.

Ajayi IA, Harstrup ET (n.d.). Management of university education in Nigeria: Problems and Prospects. Unpublished.

Ajayi K, Adeniji A (2009). Pursuing discipline and ethical issues in tertiary institutions in Nigeria. Afr. Res. Rev. 3(1):284-300.

Akeem AO (2017). Effects of increase in tuition fees in tertiary institutions of learning. Int. J. Educ. Sci. 1(3):140-147. Online access http://doi.org/10.1080/09751122.2017.1305747.

Albashtawi AH (2014). Students' perspectives for the encountered problems and challenges at the department of English in the college of science and arts in Aqurayyat. Int. J. Educ. Res. 2 (2):1-8.

Bolu-Steve FN, Olawuyi B, Gbolade OP (2017). Challenges encountered by students in the school special needs in Kwara State. Anadolu J. Educ. Sci. Inter. 7(11):184-202 
European Union (2012). DAC peer review: Main findings and recommendations. OECD.

Federal Republic of Nigeria (2013). National policy on education. Abuja: NERDC Press.

Joint Admissions and Matriculation Board (2018). Admission Brochure. Bwari: JP.

Kuranchie A, Twene C, Mensah MK, Arthur C (2014). The perceived corrupt practices of academic: what condition promotes them? Acad. J. Int. Stud. 3(1):189-196.

Limon MR (2016). The effect of the adequacy of school facilities on students' performance and achievement in technology and livelihood education. Int. J Acad. Res. in Progr. Educ. Dev. 5(1):45-58. Online access http://dx.doi.org/10.6007//JARPED/v5-i1/20158
Ogbonnaya E (n.d.). Problems militating against students industrial work experience scheme (SIWES). Unpublished.

Yasmin F, Saeed M, Ahmad N (2018). Challenges faced by postgraduate students: A case study of a private university in Pakistan. J. Educ. Hum. Dev. 7(1):109-116.

http://sciencewebpublishing.net/jerr 